\title{
An empirical study of the retirement and bridge employment intentions of older workers
}

Lo, Lawrence W. T. \

Department of Marketing and Management, Hang Seng Management College, Hong Kong (lawrencelo@hsmc.edu.hk)

Chan, Heidi M. L.

Hong Kong (hchan.ac@gmail.com)

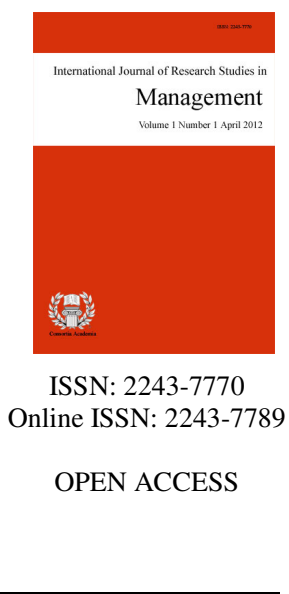

Received: 22 July 2014

Revised: 19 August 2014 DOI: 10.5861 /ijrsm.2014.863

Accepted: 20 August 2014

\section{Abstract}

This study examined the predictability of job-related, personal and family related, meaning in life and demographics factors of the retirement intentions in terms of full retirement, career and non-career bridge employment intentions of the older workers in Hong Kong. Survey interview on workers aged 50-64 ( $\mathrm{N}=280)$ was conducted. The data were analyzed through separate stepwise multiple regression models on the three retirement intentions. Interaction effects of the predictors were also inspected. Job satisfaction and negative attitude towards retirement were positively related to career and non-career bridge employment. Except for the married and aged 55-59 respondents, perceived wealth positively predicted full retirement and negatively related to career bridge employment. Contrary to prior research, perceived health had no predictive effect, and professionals reflected negative career and non-career bridge employment intentions. Further, the newly explored meaning in life factor was not a predictor. Finally, demographics exerted interaction effects on retirement intentions. In sum, Hong Kong workers showed bridge employment intentions, so designing policies to establish satisfactory working conditions and a welcoming culture to the older workers can facilitate their retention in the workforce. This study exhibited originality in disclosing the full retirement and bridge employment intentions in the context of Hong Kong. It generated values for future studies, especially in the eastern societal context. Moreover, this study combined several factor groups and newly explored the influential effect of meaning in life on retirement intentions.

Keywords: career bridge employment; non-career bridge employment; full retirement; meaning in life; Hong Kong 


\section{An empirical study of the retirement and bridge employment intentions of older workers}

\section{Introduction}

Hong Kong (HK) has been facing an aging population with the proportion of people aged 65 forecasted to rise from 13\% in 2011 to 30\% in 2041 (Census and Statistics Department, 2012a). The aging workforce is exerting economic pressure to the city, therefore, whether the retirees will return to the labor force is crucial to HK's future economic growth. Currently, there is no mandatory retirement age in HK, employers and employees are free to decide a retirement age (HK Special Administrative Region Government, 2008). Given the retirement benefit eligible age is normally perceived by workers as the usual retirement age (Zappala, Depolo, Fraccaroli, Guglielmi, \& Sarchielli, 2008), the local Mandatory Provident Fund (MPF) benefit age of 65 is generally considered as the retirement age by HK people. In order to maintain HK's competitiveness notwithstanding the aging labor force, the government has been taking steps to facilitate diverse choices of retirement life to the elderly, such that the elderly can remain as a resource to HK (HK Special Administrative Region Government, 2008). For instance, job expositions target to seniors are regularly held to assist them to re-enter the job market (HK Jockey Club, 2010). Although the government aims to preserve the older workers in the workforce, little attention has been paid to understand the retirees' preferences to stay in the labor market or to take full retirement.

Traditionally, retirement means "the end of work after a career of full time jobs" (Feldman, 1994, p.285). Within the past thirty years, however, the concept and the process of retirement have been evolving rapidly (Feldman \& Beehr, 2011; Shultz \& Wang, 2011). Retirement no longer means completely stop working (Feldman, 1994). In fact, many retirees are continuing to participate in the workforce in some ways (Kim \& Feldman, 2000). Such a kind of employment that takes place after a person departs from his/her full time career job but before his/her permanent full leisure retirement is generally described as bridge employment (Feldman, 1994; Gobeski \& Beehr, 2009; Kim \& Feldman, 2000). Bridge employment can be in the form of a full-time, part-time, temporary or self-employment (Feldman, 1994; Gobeski \& Beehr, 2009). Bridge employment can be further categorized into career bridge employment and non-career bridge employment (Feldman, 1994). Career bridge employment is employment in the same industry or field as the one before a person's retirement; whereas, non-career bridge employment is employment in an industry or field that is different from the one before an individual's retirement (Feldman, 1994; Wang, Zhan, Liu, \& Shultz, 2008).

Recent research reflects that workers have a propensity to retire earlier but more than half of the retirees are involved in bridge employment (Zhan, Wang, Liu, \& Shultz, 2009). As bridge employment redefines the concept of retirement (Wang, 2007), researchers are becomingly interested to investigate the bridge employment phenomenon. Despite the growing prevalence and importance of bridge employment, limited studies have been conducted to examine older workers' preferences of different types of retirement or bridge employment intentions (Wang et al., 2008; Zaniboni, Sarchielli, \& Fraccaroli, 2010). Besides, much retirement research has been conducted in the western societies. There appears scarce comprehensive retirement research in the eastern counterparts. In Singapore, Lim (2003) conducted a straight forward questionnaire survey on employees' attitudes towards the retirement experience; whereas Suen (1997) analyzed the HK people retirement age based on historical data. Little is known about the eastern people's retirement intentions or phenomena. Across the globe, retirement research of different countries has reflected notable result discrepancies, so the cultural background of the participants could be a contributing factor to the variability of retirement behavior (Hershey, Henkens, \& Van Dalen, 2007). Accordingly, a theoretical research gap presents in the investigation of different types of bridge employment intentions in eastern societies, such as HK.

In HK, there have been calls for the older workers to stay in the labor force after retirement, yet there appears no prior examination on the bridge employment intention of them. Therefore, there is a practical need to 
understand the bridge employment intention of the older HK workers, such that appropriate human resources policies and strategies can be devised to engage them.

To address the aforementioned theoretical and practical research gaps, this research examined older HK workers' retirement intentions, in particular their full retirement, career and non-career bridge employment intentions. The predictors of their retirement intentions were also identified. Based on the results of this study, the government and human resources professionals are able to craft courses of action to retain valuable human capital among the aging workforce. Specifically, this research sought to answer the following three research questions in the context of the older workers in HK. First, what are the retirement intentions in terms of full retirement, career bridge employment and non-career bridge employment among the older workers? Second, what factors predict the full retirement, career bridge employment and non-career bridge employment intentions? Finally, how do the predictors influence the full retirement, career bridge employment and non-career bridge employment intentions?

\section{Theoretical framework}

Researchers from different disciplines have applied diverse theories to investigate the retirement preferences and phenomena. Commonly employed theories include the continuity theory, role theory, social identity theory, stage theories, life course perspective, economic theories and motivation theories (e.g. Daniels \& Daniels, 1991; Desmette \& Gaillard, 2008; Gobeski \& Beehr, 2009; Kim \& Feldman, 2000; Wang et al., 2008; Zaniboni et al., 2010). Rooted in relevant theoretical framework, researchers generally adopted an attitudinal approach that examined the retirement intentions or preferences, or an experiential approach which investigated the retirement outcomes (Flynn, 2010).

\subsection{Continuity theory}

The continuity theory of aging by Atchley (1989) maintains that older people attempt to preserve consistent life pattern before and after retirement in order to mitigate unwelcome disruption. As such, one way for retirees to achieve continuity is to keep on working (Kim \& Feldman, 2000). Anchored in the continuity theory, Gobeski and Beehr (2009) uncovered that three work-related factors, namely job-related strain, job-related skills and intrinsic job characteristics, predicted career bridge employment of retirees.

\subsection{Role theory}

The role theory by Ashforth (2001) highlights the loss of role or redefinition of role identity in transiting from work to retirement. As Ashforth (2001) argues, being involved in a role is crucial to one's identity, which in turn affects one's behavior and decision. To smooth out the transition process of role loss, Wang et al. (2008) posits that retirees can maintain certain level of work after retirement so as to retain the work role, or take full retirement but engage in other roles if the pre-retired work role is unfulfilling. Empirically, they further proved that workers not satisfied with their jobs eventually either took full retirement or non-career bridge employment. Similarly, Zaniboni et al. (2010) observed that a negative work role identity was related to full retirement, and the anticipation of losing social integration due to loss of work role upon retirement predicted bridge employment.

\subsection{Social identity theory}

The social identity theory argues that people generally identify with groups that they perceive positively (Ashforth, 2001). As a result, workers who view retirees positively are more motivated to join the group. Desmette and Gaillard (2008) uncovered that older workers possessing self-portrayed older worker identity had the predisposition to identify with the retirees and displayed desire to retire earlier.

\subsection{Stage theories}


Researchers conceptualizing retirement as a career transition perspective also applied the career stage, life stage and family stage theories to investigate the retirement process (Feldman \& Beehr, 2011). These theories describe the time when individuals are ready to retire. According to Feldman and Beehr (2011), stage theories are related to social identity theory as the stage of the individual is very much driven by his own perception and others' perception.

\subsection{Life course perspective}

The life course perspective articulates the interdependence of different life spheres around one's life. As a result, retirement decision is influenced by various aspects of one's life, such as individual attributes, family factors and job-related factors (Wang et al., 2008). Incorporating the life course perspective, continuity theory and role theory, Wang et al. (2008) uncovered that individual attributes, job-related psychological variables and retirement planning behavior were antecedents of bridge employment decision.

\subsection{Economic theories}

Economic theories posit that retirement depends on one's financial situation. Simply stated, if one cannot financially afford to retire, one will not put retirement plan into effect (e.g. Daniels \& Daniels, 1991). Consistent with the economic theories, Kim and Feldman (2000) demonstrated that a group of US retirees who needed to financially support their children chose bridge employment as compared to their counterparts who were financially free.

\subsection{Motivation theories}

The motivation theories emphasize that retirement decision is based on the comparative motivational force between retirement and work. If retirement is more crucial in meeting the employee's needs, the employee will prefer retirement to work. Brougham and Walsh (2007) observed that older employees evaluated the incompatibility between personal goals when deciding to retiree or continue to work. In another study, Schmidt and Lee (2008) concluded that employees would choose retirement should they consider commitment to leisure activities were more instrumental in meeting their needs.

\section{Retirement intention predictors}

Prior retirement studies have identified various categories of retirement intention and decision predictors (Zappala et al., 2008). Notwithstanding the many retirement predictors classification, job-related predictors, such as job satisfaction, job characteristics, work schedule flexibility and work commitment, have been widely investigated (e.g. Gobeski \& Beehr, 2009; Pengcharoen \& Shultz, 2010; Wang et al., 2008). Further, individual and family factors, such as support dependents (e.g. Kim \& Feldman, 2000) and attitudes towards retirement (e.g. Lim, 2003) were also looked at. Finally, the influential effects of demographic characteristics, such as age and gender, on retirement were also sought by scholars (Flynn, 2010).

Researchers have applied different social science theories to understand the antecedents of retirement (Shultz \& Wang, 2011). One psychological theory that holds potential for understanding retirement is meaning in life (MIL). MIL is defined as "having a strong sense of purpose, pursuing personally valued goals, or processing a clear system of values that guide one's behavior" (Hicks, Trent, Davis, \& King, 2012, p.181). According to Reker (2000), a sense of meaning in life is "a cognizance of order, coherence, and purpose in one's existence, the pursuit and attainment of worthwhile goals, and an accompany sense of fulfillment” (p.41). Krause (2007, 2009) further operationalized MIL into four dimensions: Having values that guide one's behavior, a sense of purpose, goals, and ability to reconcile things that happened. Human being has a fundamental need to strive for a sense of meaning in life and this is particularly essential to older adults when approaching later life stage (Krause, 2007). In fact, MIL has been proved to be associated with older people's psychological well-being, quality of life and health (Krause, 2007; Krause \& Shaw, 2003). 
As people get older, they tend to develop goals that make them emotionally satisfied; furthermore, older people can achieve a sense of purpose and a deeper meaning in life if they are part of a larger group (Krause, 2007). Therefore, it makes sense to suggest that older people who enjoy a sense of meaning in life from work prefer to take bridge employment upon retirement. Alternatively, older workers who do not have meaningful goals, a sense of purpose and meaning may want to change their life patterns upon retirement. As such, they may incline to choose full retirement in order to allow more flexibility to achieve their meaning in life. This suggestion is also coherent with motivation theories in that people are motivated to make choices that meet their goals and needs (Feldman \& Beehr, 2011).

To understand the retirement intentions of the older workers in the context of HK, this research applied an attitudinal approach to examine the predictability of four groups of factors on the types of retirement intentions in terms of full retirement, career bridge and non-career bridge employment. The first three groups of factors were drawn on retirement literature, namely, job-related factors, personal and family factors and demographic factors. The last group of factor was MIL which seemed first being explored in the retirement research stream. A proposed conceptual model summarizing the following hypotheses is depicted in Figure 1.

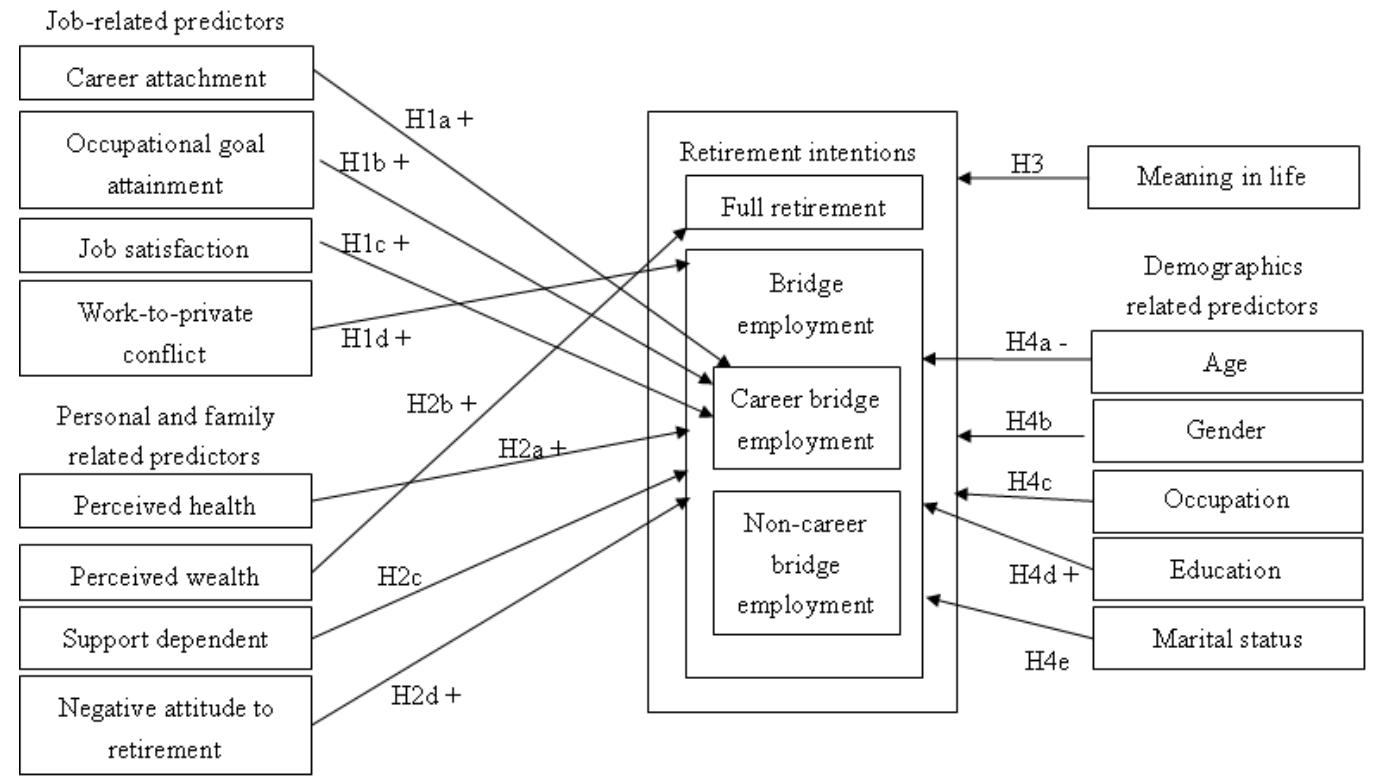

Figure 1. A proposed model of the retirement intention predictors of the older workers in Hong Kong

\subsection{Job-related retirement intention predictors}

Job-related factors have been extensively investigated in the retirement literature. Indeed, job-related characteristics and attitudes are most likely to affect the predictability of bridge employment intention (Gobeski \& Beehr, 2009). Examples of job-related predictors from prior research are shown in Table 1. Among the job-related predictors, career attachment, occupational goal attainment, job satisfaction and work-to-private conflict were examined in this research. The first three suggested predictors are concerned with work or career attitudes which appear related to bridge employment (Gobeski \& Beehr, 2009). The last proposed predictor is particularly relevant to $\mathrm{HK}$ as work life balance is an issue in this city (The University of HK, 2008).

Career attachment - Career attachment refers to the positive affect one relates to his/her career (Gobeski \& Beehr, 2009). The continuity theory suggests that older people prefer to maintain the same internal and external structures upon retirement (Wang et al., 2008). Empirical research by Gobeski and Beehr (2009) concluded that workers with a high level of career attachment took career bridge employment rather than full retirement or non-career bridge employment. 


\section{Table 1}

Examples of job-related retirement intention predictors

\begin{tabular}{|c|c|c|c|}
\hline Predictors & Authors & Methodologies & Results \\
\hline Career attachment & Gobeski \& Beehr (2009) & $\begin{array}{l}\text { Multinominal logistic } \\
\text { regression }\end{array}$ & $\begin{array}{l}0.071 * \mathrm{CB} \text { vs. FR } \\
-0.073 * \mathrm{NCB} \text { vs. } \mathrm{CB}\end{array}$ \\
\hline $\begin{array}{l}\text { Occupational goal } \\
\text { attainment }\end{array}$ & Gobeski \& Beehr (2009) & $\begin{array}{l}\text { Multinominal logistic } \\
\text { regression }\end{array}$ & $-0.149 * *$ NCB vs. CB \\
\hline Job satisfaction & $\begin{array}{l}\text { Wang, Zhan, Liu, \& Shultz } \\
\text { (2008) }\end{array}$ & $\begin{array}{l}\text { Multinominal logistic } \\
\text { regression }\end{array}$ & $\begin{array}{l}0.32 * * \mathrm{CB} \text { vs. } \mathrm{FR} \\
0.37 * * \mathrm{CB} \text { vs. } \mathrm{NCB}\end{array}$ \\
\hline $\begin{array}{l}\text { Work-to-private } \\
\text { conflict }\end{array}$ & Desmette \& Gaillard (2008) & Hierarchical regression & $0.215^{* *} \mathrm{BE}$ \\
\hline Work stress & $\begin{array}{l}\text { Wang, Zhan, Liu, \& Shultz } \\
\text { (2008) }\end{array}$ & $\begin{array}{l}\text { Multinominal logistic } \\
\text { regression }\end{array}$ & $\begin{array}{l}-0.73 * * \text { CB vs. FR } \\
-0.37 * * \text { NCB vs. FR } \\
-0.36 * * \text { CB vs. NCB }\end{array}$ \\
\hline Job related skills & Gobeski \& Beehr (2009) & $\begin{array}{l}\text { Multinominal logistic } \\
\text { regression }\end{array}$ & $0.059 * * \mathrm{CB}$ vs. FR \\
\hline $\begin{array}{l}\text { Intrinsic job } \\
\text { characteristics }\end{array}$ & Gobeski \& Beehr (2009) & $\begin{array}{l}\text { Multinominal logistic } \\
\text { regression }\end{array}$ & $\begin{array}{l}0.118 * \mathrm{CB} \text { vs. FR } \\
-0.133 * * \mathrm{NCB} \text { vs. } \mathrm{CB}\end{array}$ \\
\hline Work importance & $\begin{array}{l}\text { Zappala, Depolo, Fraccaroli, } \\
\text { Guglielmi, \& Sarchielli (2008) }\end{array}$ & Hierarchical regression & $0.14 *$ late retirement \\
\hline
\end{tabular}

Hypothesis 1a: Career attachment will be positively related to career bridge employment.

Occupational goal attainment - To minimize the possible disruption from retirement, the continuity theory posits that people who have accomplished their occupational goal during their career jobs tend to continue in the same career after retirement age. This phenomenon has also been proven by Gobeski and Beehr (2009) among a group of US retirees.

Hypothesis 1b: Occupational goal attainment will be positively related to career bridge employment.

Job satisfaction - Through a meta-analysis of previous retirement studies, Topa, Moriano, Depolo, Alcover, and Morales (2009) concluded that job satisfaction was negatively related to retirement planning and decision. Specifically, Wang et al. (2008) evidenced that job satisfaction was positively related to career bridge job rather than full retirement and non-career bridge employment. Another study by Gobeski and Beehr (2009) asking US retirees to relate back to the past also confirmed that job satisfaction of prior job was related to career bridge than non-career bridge job. Those observable facts align with the role theory which argues that people have the predisposition to preserve the same satisfactory and fulfilling work role upon retirement.

Hypothesis 1c: Job satisfaction will be positively related to career bridge employment.

Work-to-private conflict - One strategy of coping with work-to-private conflict is the avoidance/surrender approach which may result in showing sign of voluntary withdrawal from work (Akanji, 2013). Desmette and Gaillard (2008) revealed that older employees experiencing work-to-private conflict preferred bridge employment in the form of reduced working hours rather than retirement. This indicates that older workers still prefer to remain in the labor force but seek to mitigate work-to-private conflict through changing job characteristics to meet their needs.

Hypothesis 1d: Work-to-private conflict will be positively related to type(s) of bridge employment.

\subsection{Personal and family related retirement intention predictors}

Life course perspective suggests that individual attributes and family factors are among the aspects of life that affect one's retirement decision (Wang et al., 2008). Table 2 depicts some of the personal and family related 
factors that impact retirement intentions.

\section{Table 2}

Examples of personal and family related retirement intention predictors

\begin{tabular}{|c|c|c|c|}
\hline Predictors & Authors & Methodologies & Results \\
\hline Perceived health & Desmette \& Gaillard (2008) & $\begin{array}{l}\text { Hierarchical } \\
\text { regression }\end{array}$ & $-0.264 * * \mathrm{BE}$ \\
\hline Health & Kim \& Feldman (2000) & $\begin{array}{l}\text { Hierarchical } \\
\text { regression }\end{array}$ & $0.281 * * * \mathrm{BE}$ \\
\hline Health & $\begin{array}{l}\text { Wang, Zhan, Liu, \& Shultz } \\
\text { (2008) }\end{array}$ & $\begin{array}{l}\text { Multinominal logistic } \\
\text { regression }\end{array}$ & $\begin{array}{l}0.35 * * \text { CB vs. FR } \\
0.38 * * \text { NCB vs. FR }\end{array}$ \\
\hline Perceived wealth & Desmette \& Gaillard (2008) & $\begin{array}{l}\text { Hierarchical } \\
\text { regression }\end{array}$ & $0.307 * *$ early retirement \\
\hline $\begin{array}{l}\text { Financial situation } \\
\text { adequate for retirement }\end{array}$ & $\begin{array}{l}\text { Zappala, Depolo, Fraccaroli, } \\
\text { Guglielmi, \& Sarchielli (2008) }\end{array}$ & $\begin{array}{l}\text { Hierarchical } \\
\text { regression }\end{array}$ & $0.24 * *$ late retirement \\
\hline $\begin{array}{l}\text { No. of dependent } \\
\text { children }\end{array}$ & Kim \& Feldman (2000) & $\begin{array}{l}\text { Hierarchical } \\
\text { regression }\end{array}$ & $0.130 * \mathrm{BE}$ \\
\hline $\begin{array}{l}\text { Negative attitude } \\
\text { towards retirement }\end{array}$ & $\begin{array}{l}\text { Zappala, Depolo, Fraccaroli, } \\
\text { Guglielmi, \& Sarchielli (2008) }\end{array}$ & $\begin{array}{l}\text { Hierarchical } \\
\text { regression }\end{array}$ & $0.14 *$ late retirement \\
\hline
\end{tabular}

Perceived health - Good health status provides the capacity for retirees to work; therefore, good health is generally regarded as an important driver for retirees to participate in bridge employment (Zhan et al., 2009). On the other hand, retirees experiencing health problems have constraints on job performance and employability. As a result, older workers experiencing poor health will consider full retirement (Topa et al., 2009). Empirically, Kim and Feldman (2000) confirmed that good health was positively related to bridge employment. Likewise, Wang et al. (2008) found out that retirees with severe health problems were more likely to retire than to take on bridge job.

Hypothesis 2a: Perceived health will be positively related to type(s) of bridge employment.

Perceived wealth - As explained by economic theories, retirement can only be realized with affordable wealth. Therefore, it makes sense to infer that the greater the perceived wealth, the lower the intention to continue working after retirement. Desmette and Gaillard (2008) concluded that perceived wealth was positively related to early retirement. Indeed, alongside with good health status, financial pressure is another motivator for retirees to engage in bridge employment (Zhan et al., 2009). However, contrasting results were illustrated by Zappala et al. (2008) in that employees in better financial situation preferred late retirement rather than early retirement. Given the inconsistent findings, the logical relationship between perceived wealth and retirement intentions as posited by economic theories was hypothesized in this study.

Hypothesis 2b: Perceived wealth will be positively related to full retirement.

Support dependent - Coherent with economic theories, retirees who need to continue to support their children financially are more likely to take bridge employment rather than full retirement (Kim \& Feldman, 2000). Such desire to work does not only driven by the income from work to finance children's education, but also the dependent medical benefits provided by employers (Flynn, 2010).

Hypothesis 2c: Support dependent will be positively related to type(s) of bridge employment.

Negative attitude towards retirement - Topa et al. (2009)'s meta-analysis of retirement studies concluded that positive attitude towards retirement was related to retirement planning and decision. This phenomenon is consistent with the social identity theory suggesting that people generally associate with groups they perceive positively. On the same token, Zappala et al. (2008) confirmed that negative attitude towards retirement was related to late retirement. In sum, individuals with negative attitude towards retirement have the predisposition to remain in the workforce. 
Hypothesis 2d: Negative attitude towards retirement will be positively related to type(s) of bridge employment.

\subsection{Meaning in life retirement intention predictors}

As outlined previously, it seems that no research has investigated the relationship between MIL and retirement intentions. Due to the lack of theoretical and empirical guidance, an exploratory hypothesis proposing that MIL was influential on different types of retirement intentions was made.

Hypothesis 3: Meaning in life will be related to type(s) of retirement intentions.

\subsection{Demographics related retirement intention predictors}

Many researchers have investigated the predictability of demographics on retirement intentions (Flynn, 2010). Demographic factors, such as age and gender, have founded to either exert main effects or as moderators that impact the retirement decision (Topa et al., 2009). Table 3 shows some of the findings on the relationship between demographics and retirement intentions.

Table 3

Examples of demographics related retirement intention predictors

\begin{tabular}{|c|c|c|c|}
\hline Predictors & Authors & Methodologies & Results \\
\hline Age & Desmette \& Gaillard (2008) & Hierarchical regression & $-0.110 * \mathrm{BE}$ \\
\hline Age & Kim \& Feldman (2000) & Hierarchical regression & $-0.016 * * \mathrm{BE}$ \\
\hline Age & $\begin{array}{l}\text { Zappala, Depolo, Fraccaroli, } \\
\text { Guglielmi, \& Sarchielli (2008) }\end{array}$ & Hierarchical regression & $0.36^{* *}$ late retirement \\
\hline Gender & $\begin{array}{l}\text { Wang, Zhan, Liu, \& Shultz } \\
\text { (2008) }\end{array}$ & $\begin{array}{l}\text { Multinominal logistic } \\
\text { regression }\end{array}$ & $-0.48 *$ NCB vs. FR \\
\hline Education (years) & $\begin{array}{l}\text { Wang, Zhan, Liu, \& Shultz } \\
\text { (2008) }\end{array}$ & $\begin{array}{l}\text { Multinominal logistic } \\
\text { regression }\end{array}$ & $\begin{array}{l}0.08 * * \text { CB vs. FR } \\
0.15 * * \mathrm{NCB} \text { vs. FR }\end{array}$ \\
\hline Working Spouse & Kim \& Feldman (2000) & Hierarchical regression & $0.248 * * \mathrm{BE}$ \\
\hline
\end{tabular}

Age - Desmette and Gaillard (2008) illustrated that bridge employment was more preferred by workers of aged 50-54 than 55-59. This may due to the fact that the younger group had not yet identified themselves as 'older workers' both socially and psychologically; therefore, they did not consider approaching retirement and preferred to work continually. Kim and Feldman (2000) also confirmed that age of the retirees was negatively related to bridge employment. Whereas, Zappala et al. (2008) revealed that the younger employees preferred early retirement, while the older ones preferred late retirement. Given the inconclusive findings, the results of Desmette and Gaillard, and Kim and Feldman were adopted in this study.

Hypothesis 4a: Age will be negatively related to type(s) of bridge employment.

Gender - There has been some controversy in the literature about the predictability of gender on retirement intentions (Flynn, 2010; Topa et al., 2009). Some researchers argue that women have longer working lives as greater wealth is needed to support longer lives (Adam \& Rau, 2004), while some argue that the labor market favoring men causing women have difficulty maintaining work after retirement (Lissenburgh \& Smeaton 2003 cited in Flynn 2010, p.309). Wang et al. (2008) demonstrated that women negatively predicted non-career bridge employment versus full retirement. As there seems no empirical evidence in relations to the Asian culture, a general hypothesis was proposed.

Hypothesis 4b: Gender will be related to type(s) of retirement intentions.

Occupation - Professionals have better control of their working hours, therefore they are likely to take bridge job in the forms of consultancy or contractual basis upon retirement; whereas, senior executives are able 
to or affordable to move to lower level and pay jobs, so they have better opportunities to continue working after retirement (Flynn, 2010). As such, an individual's occupation has an influential effect on retirement intentions.

Hypothesis 4c: Occupation will be related to type(s) of retirement intentions.

Education - Better educated people tend to have professional knowledge or skill, they are more likely to engage in bridge employment than full retirement (Wang et al., 2008). Education level also associates with job search efficacy which has a positive impact on retirees' preferences to continue working after retirement (Adam \& Rau, 2004).

Hypothesis 4d: Education will be positively related to type(s) of bridge employment.

Marital status - Married couples can sustain similar level of interaction with each other should both are working; as such, retirees with working spouse predicted bridge employment (Kim \& Feldman, 2000). Comparable to the argument on the support dependent predictor, married retirees with family may prefer to continue working so as to provide sufficient financial support (Lewis \& Smithson, 2006). In fact, Desmette and Gaillard (2008) demonstrated that people not living with spouse inclined not to take bridge employment. It seems that having a spouse is a predictor of bridge employment.

Hypothesis 4e: Being married will be related to type(s) of bridge employment.

\section{Method}

\subsection{Data collection procedure}

A questionnaire survey targeted to workers aged between 50 and 64 (which is below the MPF benefit age of 65) was conducted. Such an age group was chosen as workers generally start to consider retirement when reaching their fifties; further, prior studies reflect that the benefit eligibility age is perceived by most workers as the usual retirement age (Zappala et al., 2008). Drawing on previous literature, an English questionnaire was developed. The questionnaire was then translated to Chinese and proof read by experienced researchers. A pilot test of twenty interviews was conducted before the actual survey to ensure face validity (Cavana, Delahaye, \& Sekaran, 2001). In response to the comments of the pilot test, few changes were made to the questionnaire, such as adding subheadings to guide the interviewers and interviewees, rephrasing a few wordings and giving examples on occupation.

Four trained interviewers who were business degree students conducted the actual survey. They identified respondents through street intercept convenience sampling in major commercial areas in HK. The interviewers first explained the meanings of retirement, career bridge employment and non-career bridge employment to the respondents to ensure they answered the questions properly.

\subsection{Participants}

A total of 280 usable questionnaires were collected, which consisted of 151 (54\%) male and $129(46 \%)$ female. $218(78 \%)$ of the participants were married. In terms of age groups, $120(43 \%)$ belonged to aged 50-54, 112 (40\%) were aged 55-59 and 48 (17\%) were 60-64 years old. Regarding education level, majority of the respondents had secondary education $(54 \%)$, followed by tertiary $(18 \%)$, university $(17 \%)$, postgraduate $(8 \%)$ and primary $(3 \%)$. Finally, the occupation groups of the participants distributed in the following manner: Blue collar (36\%), other white collar (25\%), professional (21\%) and executive (18\%).

\subsection{Measures}

Except the demographic variables, participants were asked to indicate their level of agreement on each 
statement on a 7-point Likert scale, with $1=$ strongly disagree to $7=$ strongly agree.

Career attachment - This was measured by six questions adapted from the work of Ellemers, de Gilder, and van den Heuvel (1998). Similar items were applied by Gobeski and Beehr (2009), which yielded a reliability of .89. Sample items include "Your career is one of the most important things in your life" and "The ambitions in your life mainly have to do with your career".

Occupational goal attainment - Respondents were asked three questions on their occupational goal attainment. The questions were adapted from Gobeski and Beehr (2009), with reliability of .89. Sample item is "You have reached the career goals you set for yourself".

Job satisfaction - Adapting from Warr, Butcher, Robertson, and Callinan (2004), participants were asked a single question, "All things considered, you are satisfied with your job". Overall assessment was used instead of multi-items as this method can reduce respondent fatigue and improves attention; further, single item assessment has found to be strongly correlated with multi-items (Warr \& Inceoglu, 2012).

Work-to-private conflict - Three questions were adapted from Desmette and Gaillard (2008) to measure respondents' work-to-private conflict situations. Their study generated an internal reliability of .81. An example of the questions is "You often have difficulties in your private life because of the time spent at work".

Perceived health - This was assessed through a three item scale adapted from Desmette and Gaillard (2008), which produced a reliability of .88. Sample items include "Lately, you have been feeling ill" and "Lately, you have been feeling in a depressive mood"; these two questions were reversely coded in data analysis.

Perceived wealth - Adapting from Desmette and Gaillard (2008) which yielded a reliability of .86, respondents were asked three questions in relations to their financial situation. Sample question is "You can financially afford to retire".

Support dependent - To measure financial responsibility of respondents towards their dependent, respondents were asked a single question of "You still need to financially supporting your dependent when you reach retirement age". The question was modified from Kim and Feldman (2000) which focused on dependent children only.

Negative attitude towards retirement - This was measured through a three item scale adapted from Zappala et al. (2008), which produced a reliability of .92. Sample items include "Retirement causes people to age more rapidly" and "Retirement is a difficult adjustment".

Meaning in life - The four dimensions, eight items meaning in life scale of Krause (2007, 2009) was adapted. The scale generally reflected high reliability of above .85 in much research. Sample items are "You feel like you are living fully" and "You have goals and aims".

Retirement intentions - Respondents were asked three questions on their intentions to take full retirement, career bridge employment and non-career bridge employment when they could retire. The questions were adapted from Zaniboni et al. (2010). The three questions are "As soon as you can retire, you will definitely stop working", "Even when you can already retire, you will keep on working but reduce your working time, work on temporary or contract basis in the same career/industry" and "Even when you can already retire, you will keep on working by changing job type".

Demographic information - Respondents were asked to provide various demographic information, including age, gender, occupation, education and marital status. Specifically, age was categorized into 50-54, 55-59 and 60-64, and occupation was grouped according to the General Household Survey classification (Census and Statistics Department, n.d.). Age and occupation were also applied as filtering questions to ensure the respondents were within the targeted age range of aged 50 to below 64, and were not retired at the moment of the 
survey.

\subsection{Analytical strategies}

Reliability and factor analysis - To check the correlation of items within the factors, reliability analysis was performed. Principal axis factoring (PAF) factor analysis was then carried out (Sheridan \& Ong, 2011) to determine whether the items belonged to the relevant factors. The final factor structure and reliability are shown in the results section.

Variable centring and recoding - As simply entering all predictors with raw score may lead to inconsistent and misleading results in multiple regression analyses, the mean centring procedure was adopted in this study (Kraemer \& Blasey, 2004). This procedure can be a solution to avoid extreme multicollinearity and to improve the interpretability of the intercept (Shieh, 2011). In order to measure the interaction effects between a continuous and a categorical variable in regression analyses, the continuous variables in this study were multiplied by every dummy variable recoded from the original categorical variable (Aiken \& West, 1991).

Multiple regressions with continuous and categorical variables - Three independent multiple regression analyses were conducted to assess the simultaneous effects of continuous and categorical variables in the present investigation. As stepwise model was employed, the order of independent variables entered each regression equation was determined by statistical criteria generated by the stepwise procedure (Sheridan \& Ong, 2011). The results of the stepwise multiple regression analyses are depicted in the following section.

\section{Results}

Table 4 displays the means, standard deviations and inter-correlations among the studied variables. Table 5 lists the factor analysis and reliability results. Except the perceived health and support dependent factors, all other factors had Cronbach's $\alpha$ of .63 to .93, which were above the acceptable level of .6 (Nunnally, 1978 as cited in Cavana et al., 2001, p.320). Perceived health and support dependent were removed from the factor structure of the personal and family related construct accordingly. For the confirmatory factor analysis, Varimax rotation was conducted and only a few items had loadings greater than .3 on more than one factor. Results reviewed that majority of the items could measure respective factors, except MIL. For MIL, some items could not be grouped under the expected four factors structure of early studies; instead, only two factors were identified and they were labeled as value and other MIL factor. The results of the stepwise multiple regression analyses are shown in Table 6. The non-significant estimates are not presented as they are presumably non-different from zero (McNall \& Michel, 2011).

\subsection{Full retirement intention predictors}

In predicting respondents' intention towards full retirement (dependent variable), six independent variables entered the regression equation. All six independent variables together explained 33\% of the variance (R square) in full retirement intention which was highly significant as indicated by the F-value in Table 6, F $(6,270)=21.97$, $p<.01$. The other variables failed to meet the selection criteria with insignificant t-values $(p>.05)$.

The main effect predictor was perceived wealth $(\beta=.87, p<.001)$, which was independently and positively related to full retirement. The result lent support to Hypothesis $2 \mathrm{~b}$. There were five interaction effect predictors which are stated below in order of their prediction power of the dependent variable: Married $x$ Job Satisfaction ( $\beta=-.37, p<.001)$, Age 50-54 x Negative Attitude Towards Retirement $(\beta=-.22, p<.05)$, Age 55-59 x Career Attachment $(\beta=-.28, p<.05)$, Married $x$ Perceived Wealth $(\beta=-.28, p<.05)$, and Age 55-59 x Perceived Wealth ( $\beta=-.23, p<.05$ ). Obviously, demographics (marital status and age in the present study) played an interaction role in full retirement intentions, but not provided support to any hypothesis directly. 
Lo, L. W. T. \& Chan, H. M. L.

\section{Table 4}

Means, standard deviations and inter-correlations among the studied variables

\begin{tabular}{|c|c|c|c|c|c|c|c|c|c|c|c|c|c|c|c|c|c|c|}
\hline & & Mean & SD & 1 & 2 & 3 & 4 & 5 & 6 & 7 & 8 & 9 & 10 & 11 & 12 & 13 & 14 & 15 \\
\hline 1 & $\begin{array}{l}\text { Career } \\
\text { attachment }\end{array}$ & 4.81 & 0.82 & 1 & & & & & & & & & & & & & & \\
\hline 2 & $\begin{array}{l}\text { Occupational } \\
\text { goal attainment }\end{array}$ & 4.51 & 0.86 & $.386^{* *}$ & 1 & & & & & & & & & & & & & \\
\hline 3 & $\begin{array}{l}\text { Work-to-private } \\
\text { conflict }\end{array}$ & 4.56 & 0.96 & $.355^{* *}$ & .073 & 1 & & & & & & & & & & & & \\
\hline 4 & Job satisfaction & 4.87 & 0.89 & $.388^{* *}$ & $.447^{* *}$ & $.165^{* *}$ & 1 & & & & & & & & & & & \\
\hline 5 & $\begin{array}{l}\text { Perceived } \\
\text { wealth }\end{array}$ & 3.76 & 1.29 & .043 & $.251^{* *}$ & $-.191^{* *}$ & .001 & 1 & & & & & & & & & & \\
\hline 6 & $\begin{array}{l}\text { Negative } \\
\text { attitude towards } \\
\text { retirement }\end{array}$ & 3.83 & 1.22 & .012 & -.033 & .011 & -.115 & .059 & 1 & & & & & & & & & \\
\hline 7 & Value & 4.83 & 0.92 & .040 & $.185^{* *}$ & -.066 & .084 &. $\mathbf{3 3 3}^{* *}$ & .096 & 1 & & & & & & & & \\
\hline 8 & $\begin{array}{l}\text { Other meaning } \\
\text { in life }\end{array}$ & 5.04 & 0.66 & $.215^{* *}$ & $.281^{* *}$ & -.078 & $.256^{* *}$ & $.283^{* *}$ & $-.133^{*}$ & $.458^{* *}$ & 1 & & & & & & & \\
\hline 9 & Full retirement & 3.52 & 1.41 & $-.151^{*}$ & .000 & $-.133^{*}$ & $-.208^{* *}$ & $.455^{* *}$ & -.066 & .077 & .050 & 1 & & & & & & \\
\hline & $\begin{array}{l}\text { Career bridge } \\
\text { employment }\end{array}$ & 4.55 & 1.48 & $.154^{*}$ & .039 & .095 & $.252^{* * *}$ & $-.299^{* *}$ & $.179^{* *}$ & .011 & .027 & $-.778^{* *}$ & 1 & & & & & \\
\hline & $\begin{array}{l}\text { Non-career } \\
\text { bridge } \\
\text { employment }\end{array}$ & 3.85 & 1.48 & $.182^{* * *}$ & $.131^{*}$ & .021 & $.268^{* *}$ & -.044 & $.200^{* * *}$ & .076 & .056 & $-.540^{* *}$ & $.648^{* *}$ & 1 & & & & \\
\hline & Age & 1.74 & 0.73 & $.125^{*}$ & $.189^{* * *}$ & -.023 & $.131^{*}$ & -.035 & .036 & -.050 & -.010 & -.077 & .078 & .006 & 1 & & & \\
\hline & Occupation & 3.79 & 1.12 & $-.236^{* *}$ & $-.178^{* *}$ & $-.174^{* *}$ & $-.128^{*}$ & $-.152^{*}$ & -.043 & $-.119^{*}$ & $-.132^{*}$ & -.036 & $.177^{* * *}$ & .030 & .016 & 1 & & \\
\hline & Gender & 0.46 & 0.5 & $-.242^{* *}$ & -.086 & $-.144^{*}$ & $-.181^{* *}$ & $.189^{* * *}$ & .057 & .116 & .037 & $.167^{* *}$ & $-.189^{* *}$ & $-.127^{*}$ & $-.234^{* *}$ & $-.143^{*}$ & 1 & \\
\hline & Education & 2.74 & 1.04 & $.291^{* *}$ & .077 & $.128^{*}$ & .111 & $.193^{* *}$ & -.103 & .064 & $.236^{* * *}$ & $.158^{* *}$ & $-.217^{* *}$ & -.035 & -.106 & $-.473^{* *}$ & -.102 & 1 \\
\hline 16 & Marital status & 0.78 & 0.42 & .005 & -.014 & .038 & -.009 & $.142^{*}$ & -.002 & .095 & $.119^{*}$ & .095 & -.081 & -.073 & -.023 & .029 & -.008 & .000 \\
\hline
\end{tabular}

\section{Table 5}

Factor analysis and reliability results

\begin{tabular}{lcc}
\multicolumn{1}{c}{ Factor Analysis Results } & No. of Item & Cronbach's Coefficients $(\alpha)$ \\
\hline Job-related factors & & $\mathbf{0 . 8 5}$ \\
Career attachment & 6 & 0.88 \\
Occupational goal attainment & 3 & 0.81 \\
Job satisfaction & 1 & NA (single item) \\
Work-to-private conflict & 3 & 0.78 \\
Personal and family related factors & & $\mathbf{0 . 7 3}$ \\
Perceived wealth & 3 & 0.93 \\
Negative attitude towards retirement & 3 & 0.83 \\
Meaning in life factors & & $\mathbf{0 . 8 3}$ \\
Values & 2 & 0.81 \\
Other MIL & 6 & 0.76 (Purpose) \\
& & 0.85 (Goals) \\
Demographics related factors & & 0.63 (Reflections on the past) \\
age, gender, occupation, education and marital status & 5 & NA (categorical) \\
\hline
\end{tabular}

\subsection{Career bridge employment intention predictors}

Seven independent variables entered the regression equation in predicting respondents' intention towards career bridge employment (dependent variable). All seven independent variables together explained $28 \%$ of the variance ( $\mathrm{R}$ square) in career bridge employment intention, yielding a highly significant F-value of $\mathrm{F}$ $(7,271)=14.44, p<.01$ as shown in Table 6 . Among the seven independent variables, four revealed main effect, namely, perceived wealth $(\beta=-.34, p<.001)$, job satisfaction $(\beta=.40, p<.001)$, negative attitude towards retirement $(\beta=.34, p<.001)$, and occupation variables in terms of professional $(\beta=-.60, p<.01)$ and executive $(\beta=-.45, p<.05)$. Job satisfaction was positively related to career bridge employment intention, so Hypothesis 1c was supported. Negative attitude towards retirement positively predicted career bridge employment, lending support to 
An empirical study of the retirement and bridge employment intentions of older workers

Hypothesis 2d. Occupation (professional and executive) independently and negatively predicted career bridge employment, confirming that occupation is related to retirement intention. Hypothesis $4 \mathrm{c}$ was supported.

Two interaction effects existed, which were Age 55-59 x Job Satisfaction $(\beta=.46, p<.05)$ and Professional $x$ Negative Attitude Towards Retirement $(\beta=-.34, p<.05)$. The remaining variables failed to meet the selection criteria with insignificant t-values $(p>.05)$.

\section{Table 6}

Predictors and $R$ square of the studied variables upon stepwise multiple regression analyses

\begin{tabular}{|c|c|c|c|c|c|}
\hline \multicolumn{2}{|l|}{ Full retirement } & \multicolumn{2}{|c|}{ Career bridge employment } & \multicolumn{2}{|c|}{ Non-career bridge employment } \\
\hline$R^{2}=0.33$ & $\beta$ & $R^{2}=0.28$ & $\beta$ & $R^{2}=0.20$ & $\beta$ \\
\hline $\begin{array}{l}F(6,270)=21.97, \\
p<0.01\end{array}$ & & $\begin{array}{l}F(7,271)=14.44, \\
p<0.01\end{array}$ & & $\begin{array}{l}F(5,271)=13.12, \\
p<0.01\end{array}$ & \\
\hline perceived wealth & $0.87 * * *$ & perceived wealth & $-0.34 * * *$ & $\begin{array}{l}\text { married } \mathrm{x} \text { job } \\
\text { satisfaction }\end{array}$ & $0.51 * * *$ \\
\hline $\begin{array}{l}\text { married } \mathrm{x} \text { job } \\
\text { satisfaction }\end{array}$ & $-0.37 * * *$ & job satisfaction & $0.40 * * *$ & $\begin{array}{l}\text { age } 50-54 \mathrm{x} \\
\text { negative attitude } \\
\text { towards retirement }\end{array}$ & $0.40 * * *$ \\
\hline $\begin{array}{l}\text { age } 50-54 \mathrm{x} \text { negative } \\
\text { attitude towards } \\
\text { retirement }\end{array}$ & $-0.22 *$ & $\begin{array}{l}\text { negative attitude } \\
\text { towards retirement }\end{array}$ & $0.34 * * *$ & professional & $-0.84 * * *$ \\
\hline $\begin{array}{l}\text { age } 55-59 \times \text { career } \\
\text { attachment }\end{array}$ & $-0.28 *$ & professional & $-0.60 * *$ & $\begin{array}{l}\text { postgraduate } \\
\text { education } \mathrm{x} \text { career } \\
\text { attachment }\end{array}$ & $0.60 * *$ \\
\hline $\begin{array}{l}\text { married } \mathrm{x} \text { perceived } \\
\text { wealth }\end{array}$ & $-0.28 *$ & $\begin{array}{l}\text { age } 55-59 \times \text { job } \\
\text { satisfaction }\end{array}$ & $0.46^{*}$ & $\begin{array}{l}\text { tertiary and } \\
\text { university education } \\
\mathrm{x} \text { career attachment }\end{array}$ & $0.27 *$ \\
\hline \multirow{2}{*}{$\begin{array}{l}\text { age } 55-59 \times \text { perceived } \\
\text { wealth }\end{array}$} & $-0.23 *$ & executive & $-0.45^{*}$ & & \\
\hline & & $\begin{array}{l}\text { professional } \mathrm{x} \text { negative } \\
\text { attitude towards } \\
\text { retirement }\end{array}$ & $-0.34 *$ & & \\
\hline
\end{tabular}

\subsection{Non-career bridge employment intention predictors}

Five independent variables entered the regression equation in predicting respondents' intention towards non-career bridge employment (dependent variable). The rest failed to meet the selection criteria with insignificant t-values $(p>.05)$. All five independent variables together explained $20 \%$ of the variance (R square) in non-career bridge employment intention which was highly significant as indicated by the F-value in Table 6 , F $(5,271)=13.12, p<.01$. Main effects variable was professional under the occupation variable $(\beta=-.84, p<.001)$. Professional negatively predicted both career bridge and non-career bridge employment, reinforcing Hypothesis $4 \mathrm{c}$ which states that occupation is related to type(s) of retirement intentions.

Variables that exerted interaction effects on non-career bridge employment in order of their prediction power were: Married x Job Satisfaction $(\beta=.51, p<.001)$, Age 50-54 x Negative Attitude Towards Retirement $(\beta=.40$, $p<.001$ ), Postgraduate Education (of the education variable) $x$ Career Attachment $(\beta=.60, p<.01$ ), and Tertiary and University Education (of the education variable) $x$ Career Attachment $(\beta=.27, p<.05$ ). Being married had an influential effect on non-career bridge employment intention, thus lending support to Hypothesis 4e. Further, education exhibited positive predictive effect on non-career bridge employment through interacting with career attachment. The result provided evidence that education was related to type(s) of retirement intention. Hypothesis 4d was supported accordingly. 
Among the job-related predictors, career attachment and occupational goal attainment could not predict career bridge employment; as such, the present study failed to lend support to Hypothesis 1a and 1b. Further, work-to-private conflict could not predict any type of bridge employment. Therefore, Hypothesis $1 \mathrm{~d}$ was not supported. Regarding the personal and family related predictors, perceived health and support dependent could not enter any regression model; as such, Hypotheses $2 \mathrm{a}$ and $2 \mathrm{c}$ were not supported. In the present investigation, MIL failed to show any hypothesized effect on any retirement intention, hence, there was no support to Hypothesis 3. In the demographic group of predictors, age could not predict any type of bridge employment and gender was not related to any type of retirement intention; hence, no support was lent to Hypotheses 4a and 4b.

\section{Discussion}

In the present study, job satisfaction and negative attitude towards retirement were consistently identified in the three regression models either as main predictors or had interaction effects with other variables. Regarding job satisfaction, respondents who were satisfied with their jobs disposed towards career bridge employment, which is similar to the findings observed by prior studies (e.g. Wang et al., 2008). Such phenomenon aligns with the continuity theory arguing that older people favor preserving the same life structures in such a way that preferences they have before retirement continue after retirement (Gobeski \& Beehr, 2009). Further, married respondents with satisfied career chose not to fully retire; instead they intended to participate in non-career bridge employment. As illustrated by economic theories, financial circumstances influence retirement decision (Daniels \& Daniels, 1991). Married workers may well realize their financial responsibility to families, so they prefer to stay in the workforce. Yet, owing to the lesser family burden in HK from small family size of an average of 2.9 persons (The Hong Kong Council of Social Service, 2012), married employees may be able to choose non-career bridge employment with possible lower income. In addition, married employees may prefer to continue working so as to preserve their family and societal roles which are crucial to their identities as maintained by the role theory (Ashforth, 2001). It is interesting to observe that the aged 55-59 group of respondents with satisfied job particularly preferred to take career bridge employment. This group of respondents was not the oldest group, they may consider there is still time and room for them to advance in the same satisfying career job and have not reached the life stage of retirement yet. Plus the fact that their health condition is likely better than the older group, therefore they chose career bridge employment. In short, given enough job satisfaction, HK workers may favor having a career for financial benefit and personal role or identity.

Among the four hypothesized job-related predictors, only job satisfaction reflected significant main predictive effect on retirement intentions, confirming that job satisfaction plays a prominent role in influencing retirement planning (Topa et al., 2009). Further, the "all things considered" overall job satisfaction assessment scale was able to truly reflect respondents' job psychological views as a whole.

Respondents who viewed retirement negatively had the propensity not to fully retire, but to take up either type of bridge employment. This was particularly true among the relatively younger group (aged 50-54). Same views were shared by much prior research (e.g. Topa et al., 2009). The rationale behind such findings can be attributed to the social identity theory depicting that individuals rather not to identify with groups they view negatively. As a result, respondents considered retirement negatively tended to continue working.

Perceived wealth was also a common predictor in two regression models, presenting main and interaction effects. Perceived wealth was positively related to full retirement and negatively related to career bridge employment intentions. Posited by economic theories, retirement depends on financial affordability (e.g. Daniels \& Daniels, 1991). Financial insecurity generally leads to longer working life (Flynn, 2010). Under same logic, when financial circumstances favor retirement, HK workers preferred retirement to work. Desmette and Gaillard (2008) shared a similar view in that early retirement was positively related to perceived wealth. However, when interacting perceived wealth with marital status or age, the results reflected that perceived wealth was negatively 
related to full retirement among married respondents and respondents aged 55-59. As argued previously, married respondents prefer to preserve their family and societal roles, and to make financial contribution to the families. So they may choose not to fully retire even they have adequate wealth. For the aged 55-59 respondents, previous analysis uncovered that respondents of such age group with satisfied job preferred to take up career bridge employment, this was still the case even though they perceived a better wealth situation. This can be explained by the fact that people have sufficient financial provision have a great deal of autonomy to decide on to continue to work or retire (Flynn, 2010).

Regarding occupation, professional workers were negatively related to career bridge and non-career bridge employment; whereas, executives also negatively predicted career bridge. The results were contrary to Barnes, Parry and Taylor (2004) maintaining that professional have more autonomy to engage in bridge job. The fact that HK professional did not prefer bridge job may be contributed by the long working hours and great job demand in HK. The average working hours per week in HK was around fifty hours which have distracted workers from work life balance (The University of HK, 2008). In fact, in this investigation, professional not favored career bridge job even they considered retirement negatively. In accordance with motivation theories, there seems comparatively weaker motivational force for professional to stay in the workforce.

Career attachment displayed interaction effects with respondents of aged 55-59 and negatively predicted full retirement. Again, respondents of such age group may consider not reaching the life stage of retirement yet and there is still time for them to grow in their career. Given they affectionately attached to their career, they preferred not to fully retire. This aligns with Gobeski and Beehr (2009) suggesting that strong career attachment is negatively associated with full retirement. Similarly, workers with higher effect on their career preferred to continue working, just it is worthy to note that the better educated respondents in this study (postgraduate, university and tertiary educated) preferred to take up non-career bridge jobs. Education is generally associated with job seeking efficacy (Adam \& Rau, 2004). The better educated groups tend to have more flexibility to move around in the workforce, they may prefer to switch to non-career jobs upon retirement.

Interestingly, perceived health failed to show the hypothesized predictive effect of any retirement intention. Such a result was contradicted to much preceding research (e.g. Kim \& Feldman, 2000; Topa et al., 2009; Wang et al., 2008). As mentioned previously, the perceived health factor was not reliable and not able to enter the regression models. Probably the respondents could not accurately respond to the two negatively worded statements in the perceived health factor. Alternatively, the predictive effect of health was overshadowed by other critical predictors, such as wealth and job satisfaction. Further, inconsistent with prior research, support dependent was also not a significant predictor in the current study. In fact, the factor was not able to enter the regression model.

Finally, the newly investigated MIL factor was not identified as a significant predictor. The factor could not be identified as four dimensions as constructed by Krause $(2007,2009)$ in the factor analysis. Limited time always stimulate goal selection (Hicks et al., 2012). Probably, the respondents were still economically active, and not considered running out of time to think deeply about their MIL and to act according to their purposes and goals. Besides, the MIL concept may not be common among the people in HK, and hence not efficient in predicting retirement intentions in the context of HK.

\subsection{Limitations}

There are several possible limitations in this study. First, except the full retirement model, the R squares yielded in the other two regression models were fairly small. Given this study was first of its kind in HK, the concept of bridge employment is still relatively new to the respondents could be the explanation of the low $\mathrm{R}$ squares. Second, regression analyses could have limited the analytical power in this study. Other analytical technique, such as path analysis, may generate more interpretable and comprehensive results, in particular considering the multiple relations measurement of two or more dependent variables. Third, the cross-sectional 
design adopted in this study could only identify the intentions, but not able to generate causal relationship between intention and actual behavior (Wang et al., 2008). There is distinction between planning and making a decision (Topa et al., 2009), the cross-sectional approach restricted the applicability of the findings. Lastly, the use of convenience sampling hindered the generalizability of the findings (Wang et al., 2008).

\subsection{Implications}

This research has brought in several implications theoretically and practically. Theoretically, this study fills the research gap of retirement intentions in relations to HK. Second, the findings exhibit originality in disclosing the bridge employment intentions of the local labor force. Thirdly, this study generates value for further studies through combining work related, personal and family related, demographic and MIL factors in investigating full retirement and bridge employment intentions.

Practically, this research provides insights to the local government and human resources policy makers. Obviously, except those financially healthy, HK workers prefer to engage in bridge employment rather than full retirement. The results coincide with the government's intents of encouraging the elderly to stay in the workforce. As job satisfaction has proven to be a predictor of career bridge and non-career bridge employment, human resources policies could direct towards offering satisfactory working conditions and job characteristics that are welcomed by older workers. For instance, older workers could be motivated by hygiene factors, such as fair income. Married older workers with satisfied career also inclined to stay in their career for the sake of their family as evidenced in this research, so family-friendly human resources practices can be implemented. For example, offering options of flexible working hours as a work-life balance policy so as to promote employee-friendly culture while meeting business needs (Newaz \& Zaman, 2012) or remote working to married workers.

In response to the fact that the relatively younger groups (aged 50 to 54 and aged 55 to 59) disposed towards not to fully retire, the government could initiate training programs to such age groups to enhance their competitiveness in the job market. On the organization side, the government could also advocate the benefits of employing older employees or to promote a positive identity of older workers to the society as a whole. On the employee side, the government could help to promote the positive outcomes on health from participating in bridge employment, such as maintaining physical and mental functional level. Nevertheless, establishing an encouraging and active atmosphere in the society can help to facilitate bridge employment which ultimately not only extends older workers' contributions to the society, workers' physical and mental health could be improved (Zhan et al., 2009).

\subsection{Future Research}

Since older employees have the propensity to remain in the labor force, further investigations can be made to identify their preferences on employment conditions and job characteristics. For example, is flexible working hours, part time, job rotation to less stressful tasks welcomed by older workers? Besides, human resources professionals can be interviewed to discover their views of maintaining the older workers. Through uncovering the needs of both the employers and the employees, possible employment expectation gap between the two parties can be reduced.

The current findings revealed that professionals prefer not to engage in bridge employment. Professional service is a major economic sector in HK, employing $13.3 \%$ of the working population and contributing to 12.8\% GDP (Census and Statistics Department, 2012b). Professionals' withdrawal from the labor market has significant impact to the future economic growth of HK. Therefore, future research can study more on professional's retirement intentions and hence the possible measures to keep them in the labor force.

Finally, in conjunction with the limitation, a longitudinal research can be conducted comparing older workers' retirement intentions with actual behavior. Such that relevant policies can be made to engage more 
older yet valuable workers in the work force.

\section{Conclusion}

In sum, studies of bridge employment intentions in the eastern cities like HK is scarce and worth doing. Results reviewed that respondents perceived more wealth had higher full retirement intention, except for the group aged 55-59 and the married. Respondents with higher job satisfaction or negative attitude towards retirement had lower full retirement intention and intended to engage in career bridge or non-career bridge jobs. Contrary to previous research, professionals had lower bridge employment intention. The newly explored meaning in life factor was not a significant predictor.

This study exhibited originality in disclosing the full retirement and bridge employment intentions in the context of Hong Kong. It generated values for future studies, especially in the eastern societal context. Moreover, this study combined several factor groups and newly explored the influential effect of meaning in life on retirement intentions.

\section{References}

Adams, G., \& Rau, B. (2004). Job seeking among retirees seeking bridge employment. Personnel Psychology, 57(3), 719-744. http://dx.doi.org/10.1111/j.1744-6570.2004.00005.x

Aiken, L. S., \& West, S. G. (1991). Multiple regression: Testing and interpreting interactions. Thousand Oaks, CA: Sage.

Akanji, B. (2013). An exploratory study of work-life balance in Nigeria: Employees' perspectives of coping with the role conflicts. International Journal of Research Studies in Management, 2(2), 89-100. http://dx.doi.org/10.5861/ijrsm.2013.415

Ashforth, B. (2001). Role transitions in organizational life: An identity based perspective. Mahwah, New Jersey: Lawrence Erlbaum Associates.

Atchley, R. C. (1989). A continuity theory of normal aging. Gerontologist, 29, 183-190. http://dx.doi.org/10.1093/geront/29.2.183

Barnes, H., Parry, J., \& Taylor, R. (2004). Working after state pension age: Qualitative research. London: DWP.

Beehr, T. A. (1986). The process of retirement: A review and recommendation for future investigation. Personnel Psychology, 39, 31-55. http://dx.doi.org/10.1111/j.1744-6570.1986.tb00573.x

Brougham, R. R., \& Walsh, D. A. (2007). Image theory, goal incompatibility, \& retirement intent. International Journal of Aging \& Human Development, 65(3), 203-229. http://dx.doi.org/10.2190/AG.65.3.b

Cavana, R., Delahaye, B., \& Sekaran, U. (2001). Applied business research: Qualitative and quantitative methods. Queensland, Australia: John Wiley \& Sons.

Census and Statistics Department. (2012a). Hong Kong population projections 2012 - 2041. Retrieved August 30, 2012, from http://www.statistics.gov.hk/pub/B1120015052012XXXXB0100.pdf

Census and Statistics Department. (2012b). Hong Kong monthly digest of statistics feature article: The situation of the four key industries in the Hong Kong economy in 2010. Retrieved August 30, 2012, from http://www.statistics.gov.hk/pub/B71202FA2012XXXXB0100.pdf

Census and Statistics Department. (n.d.). General household survey. Retrieved August 30, 2012, from http://www.censtatd.gov.hk/hong_kong_statistics/statistics_by_subject/labour/GHS_tables.pdf

Daniels, C. E., \& Daniels, J. D. (1991). Factors affecting the decision to accept or reject a golden handshake. Benefits Quarterly, 7, 33-46.

Desmette, D., \& Gaillard, M. (2008). When a "worker" becomes an "older worker": The effects of age-related social identity on attitudes towards retirement \& work. Career Development International, 13(2), 168-185. http://dx.doi.org/10.1108/13620430810860567

Ellemers, N., de Gilder, D., \& van den Heuvel, H. (1998). Career-oriented versus team-oriented commitment and behavior at work. Journal of Applied Psychology, 83(5), 717-730. http://dx.doi.org/10.1037/0021-9010.83.5.717 
Lo, L. W. T. \& Chan, H. M. L.

Feldman, D. C. (1994). The decision to retire early: A review and conceptualization. The Academy of Management Review, 19(2), 285-311.

Feldman, D. C., \& Beehr, T. A. (2011). A three phase model of retirement decision making. American Psychologist, 66(3), 193-203. http://dx.doi.org/10.1037/a0022153

Flynn, M. (2010). Who would delay retirement? Typologies of older workers. Personnel Review, 39(3), 308-324. http://dx.doi.org/10.1108/00483481011030511

Gobeski, K. T., \& Beehr, T. A. (2009). How retirees work: Predictors of different types of bridge employment. Journal of Organizational Behavior, 30, 401-425. http://dx.doi.org/10.1002/job.547

Hershey, D., Henkens, K., \& Van Dalen, H. (2007). Mapping the minds of retirement planners. A cross-cultural perspective. Journal of Cross-Cultural Psychology, 38, 361-382. http://dx.doi.org/10.1177/0022022107300280

Hicks, J. A., Trent, J., Davis, W. E., \& King, L. A. (2012). Positive affect, meaning in life, and future time perspective: An application of socio-emotional selectivity theory. Psychology and Aging, 27(1), 181-189. http://dx.doi.org/10.1037/a0023965

Hong Kong Jockey Club. (2010). CADENZA supports first job expo for elderly to encourage post-retirement employment. Corporate News. Retrieved August 30, 2012, from http://corporate.hkjc.com/corporate/corporate-news/english/2010-09/news_2010091001752.aspx

Hong Kong Special Administrative Region Government. (2008). LCQ4: Retirement age. Retrieved August 30 , 2012, from http://www.info.gov.hk/gia/general/200804/16/P200804160128.htm

Kim, S., \& Feldman, D. C. (2000). Working in retirement: The antecedents of bridge employment and its consequences for quality of life in retirement. Academy of Management Journal, 43(6), 1105-1210. http://dx.doi.org/10.2307/1556345

Krause, N. (2007). Longitudinal study of social support and meaning in life. The Psychology and Aging, 22(3), 456-469. http://dx.doi.org/10.1037/0882-7974.22.3.456

Krause, N. (2009). Meaning in life and mortality. The Journal of Gerontology, 64B(4), 517-527. http://dx.doi.org/10.1093/geronb/gbp047

Krause, N., \& Shaw, B. A. (2003). Role-specific control, personal meaning, and health in late life. Research on Aging, 25(6), 559-586. http://dx.doi.org/10.1177/0164027503256695

Kraemer, H. C., \& Blasey, C. M. (2004). Centring in regression analyses: a strategy to prevent errors in statistical inference. International Journal of Methods in Psychiatric Research, 13(3), 141-151. http://dx.doi.org/10.1002/mpr.170

Lewis, S., \& Smithson, J. (2006). Final report on the project "Gender, parenthood and the changing European workplace: Young adults negotiating the work-family boundary: Transitions”. Research Institute for Health and Social Change, Manchester Metropolitan University, Manchester.

Lim, K. G. (2003). An empirical study of older workers' attitudes towards the retirement experience. Employee Relations, 25(4), 330-346. http://dx.doi.org/10.1108/01425450310483361

McNall, L. A., \& Michel, J. S. (2011). A dispositional approach to work-school conflict and enrichment. Journal of Business and Psychology, 26(3), 397-411. http://dx.doi.org/10.1007/s10869-010-9187-0

Newaz, M. T., \& Zaman, K. F. (2012). Work-life balance: Is it still a new concept in private commercial banking sector of Bangladesh? International Journal of Research Studies in Management, 1(2), 57-66. http://dx.doi.org/10.5861/ijrsm.2012.95

Pengcharoen, C., \& Shultz, K.S. (2010). The influences on bridge employment decisions. International Journal of Manpower, 31(3), 322-336. http://dx.doi.org/10.1108/01437721011050602

Reker, G. T. (2000). Theoretical perspective, dimensions, and measurement of existential meaning. In G. T. Reker \& K. Chamberlain (Eds), Exploring existential meaning: optimizing human development across the life span (pp. 39-55). Thousand Oaks, CA: Sage.

Schmidt, J. A., \& Lee, K. (2008). Voluntary retirement and organization turnover intentions: The differential associations with work and non-work commitment constructs. Journal of Business and Psychology, 22, 297-309. http://dx.doi.org/10.1007/s10869-008-9068-y

Sheridan, J. C., \& Ong, C. (2011). SPSS: analysis without anguish: version 18.0 for Windows. Queensland, 
Australia: John Wiley \& Sons.

Shieh, G. (2011). Clarifying the role of mean centring in multicollinearity of interaction effects. British Journal of Mathematical and Statistical Psychology, 64(3), 462-477. http://dx.doi.org/10.1111/j.2044-8317.2010.02002.x

Shultz, K. S., \& Wang, M. (2011). Psychological perspectives on the changing nature of retirement. American Psychologist, 66(3), 170-179. http://dx.doi.org/10.1037/a0022411

Suen, W. (1997). Retirement patterns in Hong Kong: a censored regression analysis. Journal of Population Economics, 10(4), 443-461. http://dx.doi.org/10.1007/s001480050053

Taylor, M. A., \& Shore, L. M. (1995). Predictors of planned retirement age: An application of Beehr's model. Psychology \& Aging, 10(1), 76-83. http://dx.doi.org/10.1037/0882-7974.10.1.76

The Hong Kong Council of Social Service. (2012). Family and community services in Hong Kong. Retrieved September 15, 2012, from www.hkcss.org.hk/download/folder/fc/fc_eng.doc

The University of Hong Kong. (2008). Work life balance in Hong Kong survey results. Retrieved September 20 , 2012, from http://www.hku.hk/press/news_detail_5755.html

Topa, G., Moriano, J. A., Depolo, M., Alcover, C. M., \& Morales, J. F. (2009). Antecedants and consequences of retirement planning \& decision-making: A meta-analysis and model. Journal of Vocational Behavior, 75(1), 38-55. http://dx.doi.org/10.1016/j.jvb.2009.03.002

Wang, M. (2007). Profiling retirees in the retirement transition and adjustment process: Examining the longitudinal change patterns of retirees' psychological well-being. Journal of Applied Psychology, 92(2), 455-474. http://dx.doi.org/10.1037/0021-9010.92.2.455

Wang, M., Zhan, Y., Liu, S., \& Shultz, K. S. (2008). Antecedents of bridge employment: A longitudinal investigation. Journal of Applied Psychology, 93(4), 818-820. http://dx.doi.org/10.1037/0021-9010.93.4.818

Warr, P., Butcher, V., Robertson, I., \& Callinan, M. (2004). Older people's well-being as a function of employment, retirement, environmental characteristics and role preference. British Journal of Psychology, 95, 297-324. http://dx.doi.org/10.1348/0007126041528095

Warr, P., \& Inceoglu, I. (2012). Job engagement, job satisfaction, \& contrasting associations with person-job fit. Journal of Occupational Health Psychology, 17(2), 129-138. http://dx.doi.org/10.1037/a0026859

Warren, A. M., \& Kelloway, E. K. (2010). Retirement decisions in the context of the abolishment of mandatory retirement. International Journal of Manpower, 31(3), 286-305. http://dx.doi.org/10.1108/01437721011050585

Zaniboni, S., Sarchielli, G., \& Fraccaroli, F. (2010). How are the psychological factors related to retirement intention? International Journal of Manpower, 31(3), 271-285. http://dx.doi.org/10.1108/01437721011050576

Zappala, S., Depolo, M., Fraccaroli, F., Guglielmi, D., \& Sarchielli, G. (2008). Early retirement as withdrawal behavior: Postponing job retirement? Psychosocial influences on the preferences for early or late retirement. Career Development International, 13(2), 150-167. http://dx.doi.org/10.1108/13620430810860558

Zhan, Y., Wang, M., Liu, S., \& Shultz, K. S. (2009). Bridge employment and retirees' health: A longitudinal investigation. Journal of Occupational Health Psychology, 14(4), 374-389. http://dx.doi.org/10.1037/a0015285 
Lo, L. W. T. \& Chan, H. M. L. 